\title{
Editorial for Special Issue "Minerals of Kimberlites: An Insight into Petrogenesis and the Diamond Potential of Deep Mantle Magmas"
}

\author{
Igor S. Sharygin ${ }^{1,2, *}$ and Dmitry A. Zedgenizov ${ }^{2}$ (I) \\ 1 Institute of the Earth's Crust, Siberian Branch of the Russian Academy of Sciences, 664033 Irkutsk, Russia \\ 2 Sobolev Institute of Geology and Mineralogy, Siberian Branch of the Russian Academy of Sciences, \\ 630090 Novosibirsk, Russia; zed@igm.nsc.ru \\ * Correspondence: isharygin@crust.irk.ru
}

Received: 26 October 2020; Accepted: 27 October 2020; Published: 2 November 2020

Kimberlites are igneous rocks that represent the deepest magmas originated from the mantle $(>150 \mathrm{~km})$ and typically occur within cratons. The studies of kimberlites and their mantle xenoliths provide fundamentally important information about the composition, structure, and melting history of the cratonic mantle. Kimberlites are also economically important, as they are a major source of diamonds. Kimberlites are hybrid rocks consisting of minerals of different origins: xenogenic minerals produced by the fragmentation of foreign mantle and crustal rocks (i.e., xenoliths and xenocrysts), primary minerals crystallized from kimberlite melt, and later minerals formed during the post-magmatic alteration of kimberlites. The mineralogy of individual kimberlites may be extremely variable and complex. Diamonds and their inclusions, trapped at the time of diamond growth and preserved from external processes for billions of years, help us to look into the history of cratonic lithosphere, far in the past. Occasionally, kimberlites contain diamonds derived from sublithospheric mantle. These so-called super-deep diamonds and their inclusions are the only direct source of our knowledge about the lowermost upper mantle, the transition zone or even the lower mantle. Garnet, chromite, ilmenite, chrome-diopside, and olivine serve as kimberlite indicator minerals because they occur in kimberlites in significantly higher quantities than diamonds. They are used for diamond prospecting and the primary assessment of whether a target kimberlite is diamond-bearing or not. Thus, the interpretation of mineralogical data from kimberlites is essential for an understanding of the Earth's mantle, history of cratons, kimberlite petrogenesis and diamond potential. The contributions in this Special Issue provide a new insight into petrogenesis and the diamond potential of deep mantle magmas.

The review paper of Bussweiler [1] summarizes the data on polymineralic inclusions in megacrysts, mantle minerals that are $>1 \mathrm{~cm}$, from different kimberlite localities around the world. These inclusions are likely the products of early kimberlite melt which invaded the pre-existing megacryst minerals at mantle depths and fully crystallized or quenched during the emplacement to the surface. Thus, chemical features of polymineralic inclusions in megacrysts provide the information about primary characteristics of the kimberlite melts and trace their evolution during ascent from the upper mantle to the surface.

Zhu et al. [2] have studied two genetic types of spinel in the No. 30 kimberlite pipe from Liaoning Province (North China Craton). The geochemistry of spinels was used to predict diamond potential of this kimberlite pipe. Magmatic spinels, crystallizing directly from kimberlite melt, display that the oxygen fugacity in kimberlite magma of pipe No. 30 was high, which resulted in strong diamond resorption. Xenocrystic spinels, derived from mantle xenoliths, indicated that mantle rocks sampled by kimberlite magma were diamond-barren. Both factors may be responsible for the low diamond grade of the No. 30 kimberlite pipe. 
In order to evaluate diamond exploration potential of southern Arkhangelsk region (NW Russia) Shchukina et al. [3] reconstructed the composition and metasomatic history of the lithospheric mantle beneath this area on the basis of the geochemistry of chrome-pyrope grains recovered from samples of modern rivers and stream sediment. The results showed that the lithospheric mantle beneath the studied area was suitable for the formation and preservation of diamonds. The high percentage of diamond-associated pyropes emphasizes the likelihood of high diamond contents in kimberlites to be discovered within the study area.

Tychkov et al. [4] systematized the available compositional data for olivines from mantle rocks in kimberlites from different worldwide localities. The olivines were divided into four main types. The new classification scheme allows the use of only olivine xenocrysts from kimberlites for characterisation of lithospheric mantle without time-consuming study of mantle xenoliths. This is especially important for evaluating the diamond potential of kimberlites during exploration. The authors have used this new scheme to study more than one and half thousand olivine xenocrysts from several kimberlite localities in the Siberian craton.

Dymshits et al. [5] constrained mantle paleogeotherm beneath the Komsomolskaya-Magnitnaya kimberlite pipe (Upper Muna field, Siberian craton) using clinopyroxene xenocrysts. This allowed the authors to estimate the lithosphere thickness beneath the Upper Muna field at the time of kimberlite eruption (Late Devonian-Early Carboniferous). The result demonstrates an almost similar value to the lithosphere thickness beneath the other Middle Palaeozoic kimberlite fields of the Siberian craton.

Dymshits et al. [6] further studied lithospheric mantle beneath the Upper Muna field and reported the first data on the redox state of garnet peridotites from the Komsomolskaya-Magnitnaya kimberlite pipe. It was shown that enriched (i.e. metasomatized) peridotites from the Komsomolskaya-Magnitnaya pipe are oxidized in respect to the depleted peridotites. The results also demonstrated lateral heterogeneity in the redox state of the lithospheric mantle of the Siberian craton.

Based on the study of xenoliths of extremely depleted, megacrystalline harzburgite-dunites in the Udachnaya kimberlite pipe, Pokhilenko [7] has demonstrated the presence of several generations of spinel. These samples contain primary chrome-spinel and later spinels formed during different metasomatic events: (1) ancient mantle metasomatism(s); (2) metasomatism by kimberlite melt.

Rezvukhin et al. [8] provides a detailed study of mineralogy of the orthopyroxenite xenolith from the Udachnaya kimberlite pipe. They have identified more than forty epigenetic minerals in the inclusions in rock-forming enstatite and in the intergranular space of the xenolith. The formation of these minerals has been ascribed to a series of processes superimposed onto the initial orthopyroxenite: solid solution breakdown, deep-seated mantle metasomatism, infiltration of a kimberlite-related melt and late post-emplacement hydrothermal alterations.

A complex history of a coesite-bearing diamondiferous xenolith from Udachnaya kimberlite pipe was reconstructed by Mikhailenko et al. [9]. This eclogite was formed by subduction of lower oceanic crust to $180-200 \mathrm{~km}$ at the base of the continental lithosphere. Influences of kimberlite-related melt preceding kimberlite eruption and transporting kimberlite melt caused the formation of a number of metasomatic phases in the eclogite. The main finding of the paper is the identification of olivine and orthopyroxene, typical peridotitic minerals. This fact demonstrates that the interaction of eclogite and kimberlite-related melt can produce mixed eclogite and peridotite associations.

Mixed-habit type Ib-IA diamond showing zonal and sectorial heterogeneity has been described in the xenolith of eclogite from the Udachnaya kimberlite pipe by Zedgenizov et al. [10]. The low nitrogen aggregation in the diamonds in the eclogite indicates their formation shortly before the transportation to the surface by the kimberlite magma. It was shown that nitrogen content and aggregation state vary in adjacent growth sectors of different growth zones. The observed sectorial heterogeneity indicates that aggregation of nitrogen in the octahedral sectors proceeds faster than in the cuboid sectors.

Safonov et al. [11] have reviewed the data on major phlogopite-forming reactions in upper-mantle peridotites observed in natural samples and modelled in high-pressure experiments. These data are taken as a basis for thermodynamic modelling of the phlogopite-forming reactions for mantle 
rocks using the Gibbs free energy minimization approach. It was shown that the phlogopite-forming reactions can be potentially used to estimate potassium and water activities in fluid or melt acting during metasomatism in the upper mantle.

Shatsky et al. [12] have reported new findings of silicate-melt inclusions in diamonds of eclogite paragenesis from the placers of northeastern Siberian craton. The composite inclusions in these diamonds consisting of clinopyroxene plus silicate glass were interpreted as primary melt that partially crystallized at the cooling stage. The reconstructed composition of such primary melts suggests that they were formed as the product of the interaction of host mantle substrates and slab-related melts/fluids.

Multiphase assemblages of microinclusions have been studied in cuboid diamonds from the placers of northeastern Siberian craton by Logvinova et al. [13]. The microinclusions show wide compositional variations indicating different origins and evolution of the parental media. TEM observation of microinclusions revealed specific sets of daughter phases of primary diamond-forming carbonatitic and silicic fluids/melts. These associations are believed to result from crystallization and/or quenching of fluids/melts upon their cooling.

The origin and evolution of fluids/melts in coated diamonds from Udachnaya kimberlite pipe are discussed in the paper of Gubanov et al. [14]. The fluids/melts preserved as microinclusions in the fibrous coats of these diamonds belong to two groups: high-Mg carbonatitic and low-Mg carbonatitic to silicic. The new data on major and trace elements composition suggest that high-Mg carbonatitic melts/fluids can evolve to low-Mg carbonatitic to silicic ones during percolation through different mantle lithologies.

Ragozin et al. [15] have described the evidence for the deformation of Brazilian and Siberian super-deep diamonds originating from the depth of sublithospheric mantle. It was demonstrated that these diamonds have complicated growth histories showing alternating episodes of growth, dissolution, and post-growth deformation and crushing processes. Observed features of super-deep diamonds suggest a highly dynamic environment of their formation and storage in the transition zone and lower mantle.

Tamarova et al. [16] presented new data on rare-earth elements (REE) partition coefficients between $(\mathrm{Mg}, \mathrm{Fe}) \mathrm{SiO}_{3}$-bridgmanite and $\mathrm{CaSiO}_{3}$-perovskite under the conditions of the uppermost lower mantle (21.5 and $24 \mathrm{GPa}$ ) obtained from experiments and atomistic modelling. It was shown that heavy REE are mostly accumulated in bridgmanite, while light REE are predominantly redistributed into $\mathrm{CaSiO}_{3}$. The results are applicable for interpretation of the trace-element composition of the lower mantle inclusions in super-deep diamonds. The observed effect of pressure on the bridgmanite/ $\mathrm{CaSiO}_{3}$-perovskite REE partition coefficients can be a potential qualitative geobarometer.

Funding: Support from the Russian Science Foundation (grant numbers: 18-17-00249 and 18-77-10062) and a state assignment projects of IEC SB RAS and IGM SB RAS are gratefully acknowledged.

Acknowledgments: The Guest Editors thank the Editors-in-Chief, Editors, Assistant Editors, and Reviewers for their important comments and constructive suggestions, which helped the contributing authors to improve the quality of the manuscripts. We warmly thank Sweater Shi and Irwin Liang for their kind editorial assistance during the preparation of this Special Issue. Many thanks go to the authors of the articles included in this Special Issue and the organizations that have financially supported research in the areas related to this Special Issue.

Conflicts of Interest: The authors declare no conflict of interest. 


\section{References}

1. Bussweiler, Y. Polymineralic Inclusions in Megacrysts as Proxies for Kimberlite Melt Evolution-A Review. Minerals 2019, 9, 530. [CrossRef]

2. Zhu, R.-Z.; Ni, P.; Ding, J.-Y.; Wang, G.-G. Geochemistry of Magmatic and Xenocrystic Spinel in the No. 30 Kimberlite Pipe (Liaoning Province, North China Craton): Constraints on Diamond Potential. Minerals 2019, 9, 382. [CrossRef]

3. Shchukina, E.V.; Agashev, A.M.; Shchukin, V.S. Diamond-Bearing Root Beneath the Northern East European Platform (Arkhangelsk Region, Russia): Evidence from Cr-Pyrope Trace-Element Geochemistry. Minerals 2019, 9, 261. [CrossRef]

4. Tychkov, N.S.; Agashev, A.M.; Pokhilenko, N.P.; Tsykh, V.A.; Sobolev, N.V. Types of Xenogenic Olivine from Siberian Kimberlites. Minerals 2020, 10, 302. [CrossRef]

5. Dymshits, A.M.; Sharygin, I.S.; Malkovets, V.G.; Yakovlev, I.V.; Gibsher, A.A.; Alifirova, T.A.; Vorobei, S.S.; Potapov, S.V.; Garanin, V.K. Thermal State, Thickness, and Composition of the Lithospheric Mantle beneath the Upper Muna Kimberlite Field (Siberian Craton) Constrained by Clinopyroxene Xenocrysts and Comparison with Daldyn and Mirny Fields. Minerals 2020, 10, 549. [CrossRef]

6. Dymshits, A.; Sharygin, I.; Liu, Z.; Korolev, N.; Malkovets, V.; Alifirova, T.; Yakovlev, I.; Xu, Y.-G. Oxidation State of the Lithospheric Mantle Beneath Komsomolskaya-Magnitnaya Kimberlite Pipe, Upper Muna Field, Siberian Craton. Minerals 2020, 10, 740. [CrossRef]

7. Pokhilenko, L. Formation Sequence of Different Spinel Species in Megacrystalline Peridotites of the Udachnaya-East Kimberlite Pipe (Yakutia): Evidence for the Metasomatism of Depleted Mantle. Minerals 2019, 9, 607. [CrossRef]

8. Rezvukhin, D.I.; Alifirova, T.A.; Golovin, A.V.; Korsakov, A.V. A Plethora of Epigenetic Minerals Reveals a Multistage Metasomatic Overprint of a Mantle Orthopyroxenite from the Udachnaya Kimberlite. Minerals 2020, 10, 264. [CrossRef]

9. Mikhailenko, D.; Golovin, A.; Korsakov, A.; Aulbach, S.; Gerdes, A.; Ragozin, A. Metasomatic Evolution of Coesite-Bearing Diamondiferous Eclogite from the Udachnaya Kimberlite. Minerals 2020, 10, 383. [CrossRef]

10. Zedgenizov, D.; Bogush, I.; Shatsky, V.; Kovalchuk, O.; Ragozin, A.; Kalinina, V. Mixed-Habit Type Ib-IaA Diamond from an Udachnaya Eclogite. Minerals 2019, 9, 741. [CrossRef]

11. Safonov, O.; Butvina, V.; Limanov, E. Phlogopite-Forming Reactions as Indicators of Metasomatism in the Lithospheric Mantle. Minerals 2019, 9, 685. [CrossRef]

12. Shatsky, V.; Zedgenizov, D.; Ragozin, A.; Kalinina, V. Silicate Melt Inclusions in Diamonds of Eclogite Paragenesis from Placers on the Northeastern Siberian Craton. Minerals 2019, 9, 412. [CrossRef]

13. Logvinova, A.; Zedgenizov, D.; Wirth, R. Specific Multiphase Assemblages of Carbonatitic and Al-Rich Silicic Diamond-Forming Fluids/Melts: TEM Observation of Microinclusions in Cuboid Diamonds from the Placers of Northeastern Siberian Craton. Minerals 2019, 9, 50. [CrossRef]

14. Gubanov, N.; Zedgenizov, D.; Sharygin, I.; Ragozin, A. Origin and Evolution of High-Mg Carbonatitic and Low-Mg Carbonatitic to Silicic High-Density Fluids in Coated Diamonds from Udachnaya Kimberlite Pipe. Minerals 2019, 9, 734. [CrossRef]

15. Ragozin, A.; Zedgenizov, D.; Shatsky, V.; Kuper, K.; Kagi, H. Deformation Features of Super-Deep Diamonds. Minerals 2020, 10, 18. [CrossRef]

16. Tamarova, A.P.; Marchenko, E.I.; Bobrov, A.V.; Eremin, N.N.; Zinov'eva, N.G.; Irifune, T.; Hirata, T.; Makino, Y. Interphase REE Partitioning at the Boundary between the Earth's Transition Zone and Lower Mantle: Evidence from Experiments and Atomistic Modeling. Minerals 2020, 10, 262. [CrossRef]

Publisher's Note: MDPI stays neutral with regard to jurisdictional claims in published maps and institutional affiliations. 